\title{
Research on Customer's Concept of Virtual Banking on Payment Platform with Special Reference to Customers in Chennai City
}

\author{
KamilaSharni \\ B. Com (Bank Management), Anna Adarsh College for Women, India \\ kamilasharmin786@gmail.com
}

\begin{abstract}
Virtual banking plays a critical role in these days' international in which human beings are searching past the conventional way of going to the bank for doing their bank transactions. Internet banking has converted the conventional manner of banking and has delivered new dimensions to the banking quarter. This study describes the contemporary kingdom of Virtual banking and discusses customers' belief on adoption of virtual banking in Indian context. Virtual banking has enabled the banks to decorate its operation and powerful cost reducing, but looking at the worldwide context, it still has a protracted way to head. This paper gives an in depth take a look at of clients' perception and their adaptability to these revolutionary modifications in banking. A primary survey becomes performed using a based questionnaire on the customers' stage of satisfaction and their expectancies concerning various Virtual banking services. The take a look at establishes the truth that customers are within the manner of getting acclimatized with the belief of Virtual banking and that no matter all of the challenges, their notion in the direction of Virtualization's rapid converting.
\end{abstract}

Keywords: Customers' notion, virtual banking, Adaptability of Indian banks

\section{Introduction}

Commercial financial institution is undergoing a rapid alternate towards Virtual banking. A fundamental force in the back of Virtual banking is facts era. Using IT, a financial institution can reach out to clients and provide them with no longer handiest standard facts approximately its offerings but additionally the possibility of acting interactive retail banking transactions. Commercial banks have fast realized the importance of this thing to aggressive gain. Since Nineteen Nineties, they have continuously innovated thru era - stronger merchandise and services, such as multifunctional Automatic Teller Machine (ATM), electronic share application, telephone banking, TV banking, Virtual transfers, electronic coins playing cards and Internet - based totally E - banking. even as the Virtual financial institution is the company of banking offerings via electronic media such as ATM, smartphone, non - public computers and/or Internet. The motive of this research is to analyze how one - of - a - kind Virtual banking forms are adopted or perceived in India. The findings of this study may additionally help each the financial institution manager formulate their advertising strategies to sell Virtual banking and the researchers do properly in virtual banking studies and Virtual organizations in well - known.

\section{Literature Review}

Dr. Arunangshu Giri and Ipsita Paria (2018) the article named "A Literature Review on Impact of Digitalization on Indian Rural Banking System and Rural Economy". The current paper centers around the survey and sums up different investigations which were made by various scientist of various area over India on the effect of digitalization on country banking arrangement of India. The investigation found that, computerized banking is having the capacity to change the scene of monetary consideration. The investigation additionally found that, with the highlights as minimal effort, simple of utilization advanced banking can quicken the joining of unbanked economy to the standard.

K. Hema Divya and K. Suma Vally (2018) the article named "A Study on Digital Payments in India with Viewpoint of Consumer's Adoption". The current paper centers around the examination of the appropriation level of the advanced installment frameworks by clients. Essential information was gathered from 183 respondents in Hyderabad. The gathered information through survey were dissected by utilizing chi - square method. The investigation found that, the arrangement of innovation for advanced installments have improved the presentation of banking area furthermore, ready to accomplish the thought process money less nation.

Anthony Rahul Golden S. (2017) the article named "An Overview of Digitalization in Indian Banking Area". In this article an endeavor has been made to examine the diagram of digitalization in Indian Banking area. Banks are a portion of our lives as well as have a critical part in our everyday lives. Subsequently banks consistently attempt to embrace most recent innovations to upgrade client experience. The examination found that, because of the reception of this digitalization, the financial areas in India face some exceptional changes just as obstacles. The concentrate likewise found that, as we are in the computerized time, it is beyond the realm of imagination to expect to dodge the development and administrations or computerized banking.

Santiago Carbo - Valverde (2017) the article named "The Impact on Digitalization on Banking and Monetary Stability". In this article an endeavor has been had to examine the effect of digitalization on banking exercises and difficulties that force for monetary steadiness. The examination found that, digitalization is an occasion to diminish minimal expenses and increment profitability in monetary administrations. 


\subsection{Research Gap}

Literature review proposes that there has been research tending to the significance of innovation reception and variables influencing the adaption of innovation in Indian setting. Anyway there is by all accounts research gap regarding what do the customers feel about the degree of innovation selection and what are their desires from Indian banks. This research paper means to satisfy this exploration hole.

\subsection{Research Objectives}

- To know customers' notion about the level of adaptability of virtual banking

- To perceive the elements that have an effect on customers' adoption of digitalization in banking region

- To know the customer satisfaction level of service qualities offered virtually in banks

\section{Methodology of the study}

The research adopts descriptive research design. In total 136 customers from 4 private and 4 public sector banks were surveyed adopting a structured questionnaire. The geographical area covered for the study was respondents from Chennai city. Stratified sampling was used to select the samples, where the population was divided into two strata namely, public banks and private banks.

\section{Analysis and Interpretation}

1) Which category of banks do you keep in mind as most technologically advanced?

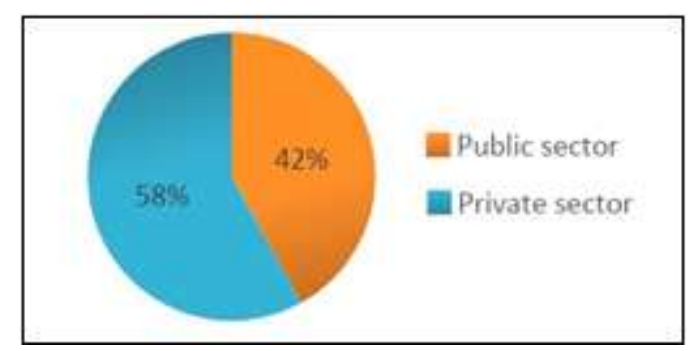

It was observed from the survey that $58 \%$ of the respondents perceive Private sector banks as more technologically advanced whereas $42 \%$ of the respondents are in favor of Public sector banks.

2) Rate the adaption of technology by using your bank products on a scale of 1 to 5 as compared to global requirements of technology adoption. ( 1 being least adaptive to five being highly adaptive)

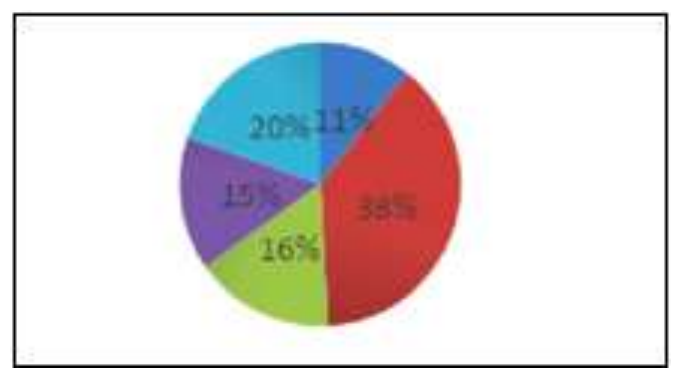

Large percentage of respondents perceives their banks to be somewhat adaptive to technology. Only $20 \%$ of the respondents believe their banks to be highly adaptive of technology. This shows that Indian banking sector has a long path ahead when it comes to adaption of technology as compared to the global standards.

\section{3) What factors make you to evolve to new technology in banking?}

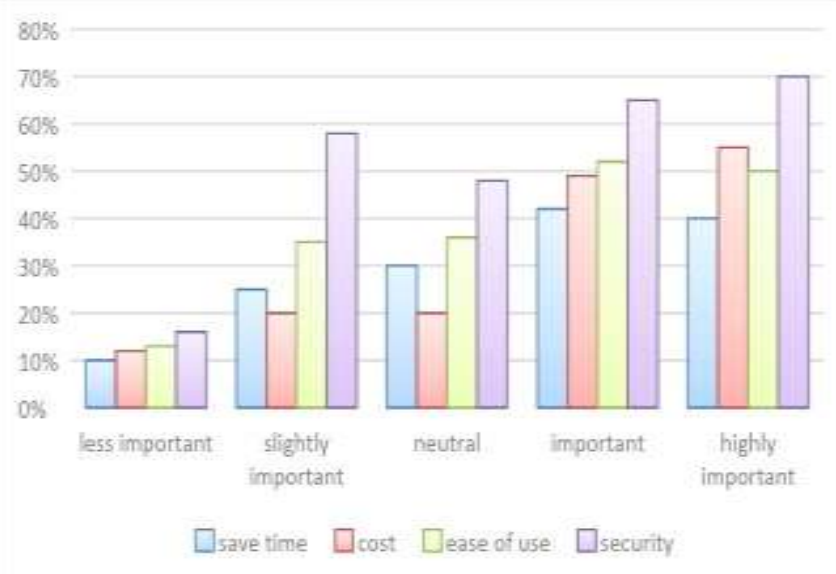

It was observed that customers consider security to be the most important factor followed by cost for adapting technology in banking.

4) Rate your satisfaction level on a scale of 1 to 5 for the following services:

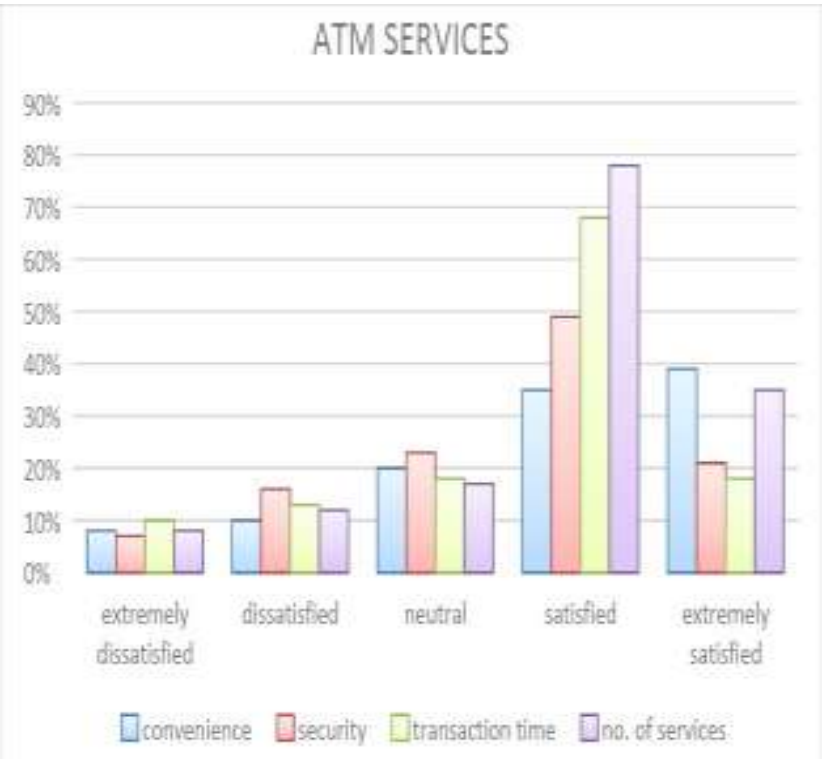

It is observed that with respect to ATM services that customers are overall satisfied with the convenience, transaction time, no. of services. However, they seem to be dissatisfied with the security offered to them via ATM 


\section{TELEPHONE BANKING}

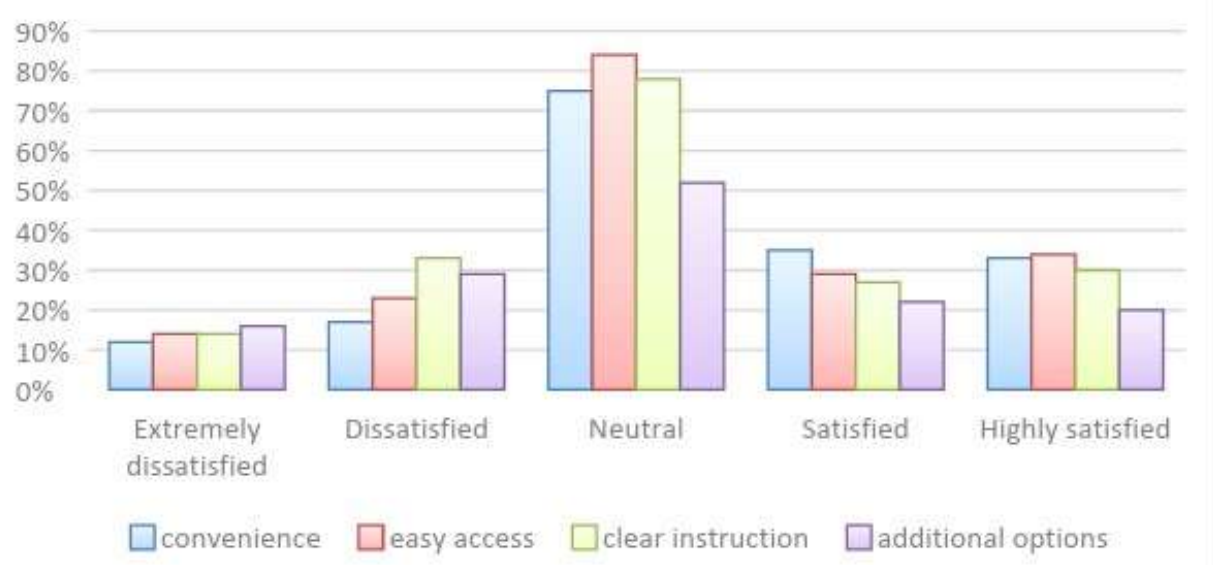

It was observed that overall customers are satisfied with the hence a large majority was neutral with their satisfaction phone banking services offered by the banks with respect to level. convenience, easy access, clear instructions and additional options. Also, users of phone banking are decreasing in no.

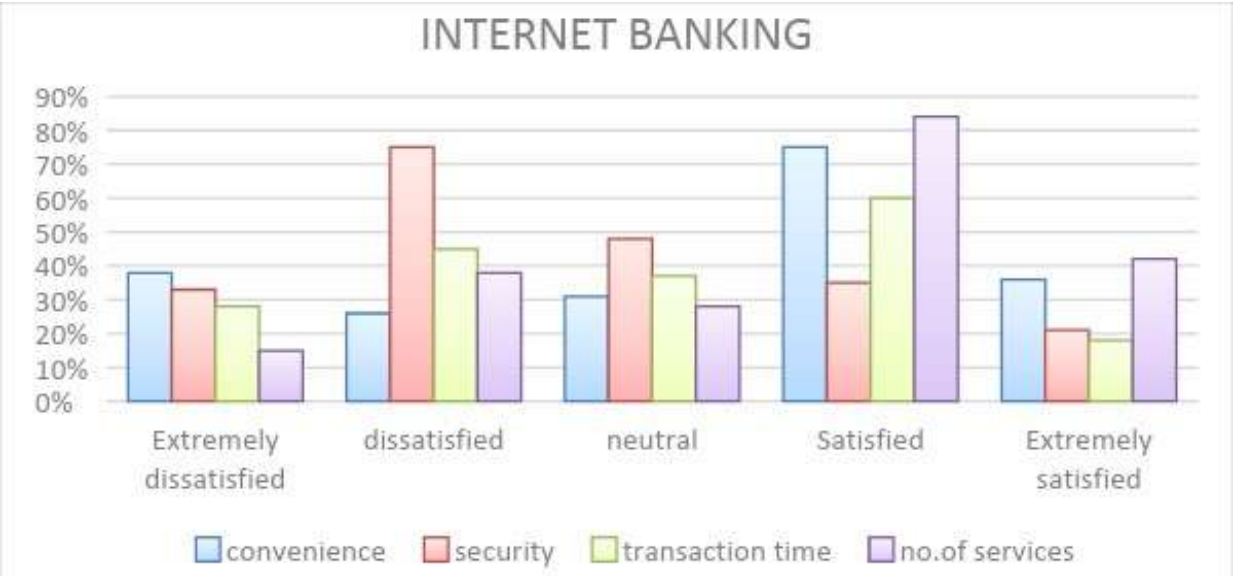

It was observed that the customers are satisfied towards convenience, security, transaction time, services offered.
However, there is dissatisfaction amongst customers with respect to security.

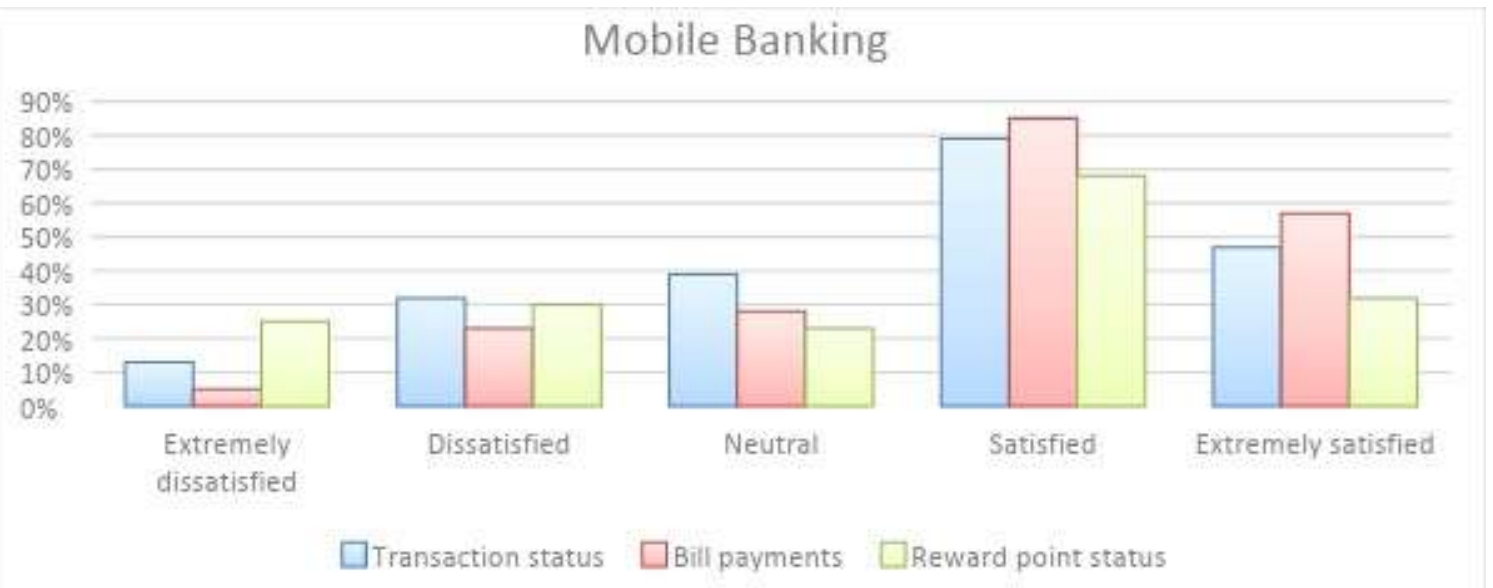

It was observed that overall; the customers seemed satisfied with mobile banking services however around $30 \%$ of them were dissatisfied with the overall services of mobile banking

5) Select the bank in which you have your account (Select any one which is primary bank for your transactions) 


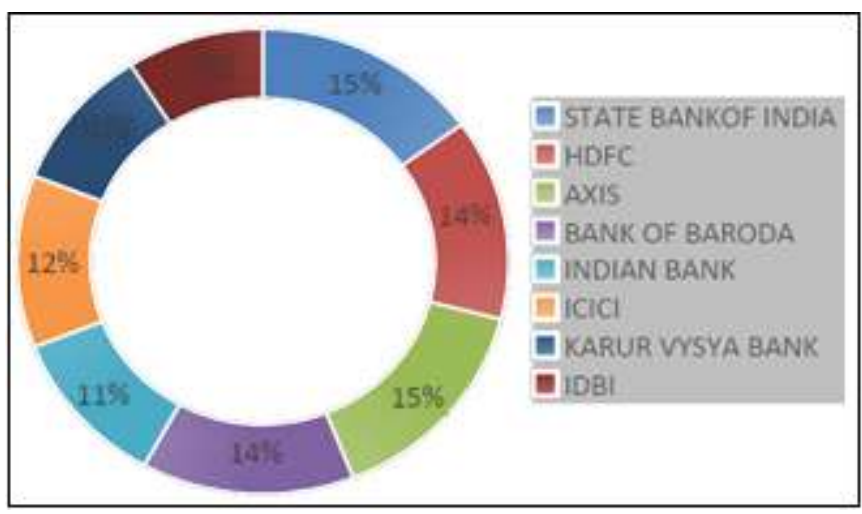

Out of 136 respondents, $50 \%$ belonged to the Private sector banks, whereas $50 \%$ belonged to the Public sector banks.

\section{Hypothesis Analysis}

To test the variableness of technology adoption and customer satisfaction between public and private sector banks

\begin{tabular}{|c|c|c|}
\hline Hypothesis & $\begin{array}{c}\begin{array}{c}\text { Significant } \\
\text { value }\end{array} \\
\end{array}$ & Decision \\
\hline $\begin{array}{l}\text { Ho: There is no differentiability in adaption of technology between Public and } \\
\text { Private sector bank H1: There is differentiability in adaption of technology } \\
\text { between Public and Private sector bank }\end{array}$ & 0.003 & $\begin{array}{l}\text { The significant value is less than table value } \\
0.05 \text {, indicating that the null hypothesis is } \\
\text { rejected and alternate hypothesis is accepted. }\end{array}$ \\
\hline $\begin{array}{l}\text { Ho: There is no differentiability in factors that e } \\
\text { between public and private sector banks } \mathrm{H} 1 \text { : The } \\
\text { that evolve adaption of technology between pu }\end{array}$ & 0.142 & $\begin{array}{l}\text { The significant value is greater than table value } \\
0.05 \text {, indicating that the null hypothesis is } \\
\text { accepted }\end{array}$ \\
\hline $\begin{array}{r}\text { Ho: There is no differentiability in satisf } \\
\text { Public and Priva }\end{array}$ & \multirow{2}{*}{0.002} & \multirow{2}{*}{$\begin{array}{l}\text { The significant value is less than } 0.05, \\
\text { indicating that the null hypothesis is rejected } \\
\text { and alternate hypothesis is accepted. }\end{array}$} \\
\hline $\begin{array}{r}\text { H1: There is differentiability in sat } \\
\text { Public and } \mathrm{F}\end{array}$ & & \\
\hline $\begin{array}{r}\text { Ho: There is no differenti: } \\
\text { betwe }\end{array}$ & \multirow{2}{*}{0.676} & \multirow{2}{*}{$\begin{array}{l}\text { The significant value is greater than } 0.05 \text {, } \\
\text { indicating that the null hypothesis is accepted. }\end{array}$} \\
\hline $\begin{array}{r}\text { H1: There is differentiability in } \mathrm{s} \\
\text { between Publi }\end{array}$ & & \\
\hline $\begin{array}{r}\text { Ho: There is no in satisfaction level for In } \\
\text { Public and Private s }\end{array}$ & \multirow{2}{*}{0.002} & \multirow{2}{*}{$\begin{array}{l}\text { The significant value is less than } 0.05 \text {, } \\
\text { indicating that the null hypothesis is rejected } \\
\text { and alternate hypothesis is accepted. }\end{array}$} \\
\hline $\begin{array}{r}\text { H1: There is differentiability in satisfaction le } \\
\text { between Public and Privat }\end{array}$ & & \\
\hline $\begin{array}{c}\text { Ho: There is no differentiability in satisfaction level for Mobile banking services } \\
\text { between Public and Private sector banks }\end{array}$ & \multirow{2}{*}{0} & \multirow{2}{*}{$\begin{array}{l}\text { The significant value is less than } 0.05 \text {, } \\
\text { indicating that the null hypothesis is rejected } \\
\text { and alternate hypothesis is accepted. }\end{array}$} \\
\hline $\begin{array}{r}\text { H1: There is differentiability in sat } \\
\text { between Public }\end{array}$ & & \\
\hline
\end{tabular}

\section{Findings}

Results advise that there's variability within the adoption of technology among private and public banks. Private region banks seem to have adopted technology higher than the Public zone banks. Overall customers notion also suggests that there are relatively happy with the technological adoption of their banks in assessment with global requirements.

With respect to elements that spark off customers to adapt new era, they do not range among personal sector banks and public region banks. Customers in widespread recall protection because the number one purpose for technology adaption.

As a long way as purchaser satisfaction is concerned with appreciate to era adaption there's variability in pleasure of clients with ATM services. Overall results advocate that customers are disappointed with the no. Of services provided through ATM by way of public sector banks.

For phone banking there appears to be no variability inside the pride level of personal and public zone banks. Results advise that majority of the clients are impartial with appreciate to this carrier supplied.

For mobile banking and internet banking offerings there appears to be variability in the pleasure degree of private sector and public sector banks. Results advocate that private region banks appear to provide better cellular banking and internet banking offerings as compared to public sector banks. Specifically, customers had problems with the website freezing at the same time as transacting with public area banks.

\section{Conclusion}

It may be concluded that banks in India nonetheless have a long way to go to suit global standards in terms of technological adoption. Specifically, public zone banks need to improve their technological adoption to create higher client pleasure. Security is the primary aspect considered critical by means of the customers to evolve era, in order that needs to be progressed via the banks. Public region banks also want to feature on extra no. Of services they offer via $\mathrm{ATM}$ in addition to improve their mobile banking and net banking offerings. 


\section{References}

[1] Raghavendra Nayak "A Conceptual Study on Digitalization of Banking - Issues and Challenges in Rural India", International Journal of management, IT and Engineering, 2018.

[2] K. Suma Vally and K. Hema Divya "A Study on Digital Payments in India with Perspective of Consumer's Adoption", International Journal of Pure and Applied Mathematics, 2018.

[3] Mathangi R., Latasri O. T. and Isaiah Onsarigo Miencha "Improving Service Quality through Digital Banking Issues and Challenges", International Journal of Recent Scientific Research, 2017.

[4] Ipsita Paria and Dr. Arunangshu Giri "A Literature Review on Impact of Digitalization on Indian Rural Banking System and Rural Economy", Research Review International Journal of Multidisciplinary, 2018.

[5] Anthony Rahul Golden S. "An Overview of Digitalization in Indian Banking Sector", Indo - Iranian Journal of Scientific Research (IIJSR), October December, 2017.

[6] Santiago Carbo - Valverde "The Impact on Digitalization on Banking and Financial Stability", Journal of Financial Management, Markets and Institutions, 2017. 